\title{
Sciendo
}

Administration, vol. 68, no. 4 (2020), pp. 121-144

doi: 10.2478/admin-2020-0027

\section{Corporate governance in the public sector: Reflections on experience in Ireland}

\author{
Aidan Horan \& Michael Mulreany \\ Institute of Public Administration, Ireland
}

\begin{abstract}
The article proceeds from the context for corporate governance in the public sector in Ireland. It examines the adoption and evolution of corporate governance guidance, standards and codes, and focuses on the Code of Practice for the Governance of State Bodies. In reflecting on the scope and depth of the provisions of the state body code, the article points to various implementation challenges using examples in the areas of culture, risk appetite and assurance arrangements. The article concludes by pointing to future challenges and suggestions for a research agenda for corporate governance in the public sector in Ireland.
\end{abstract}

Keywords: Governance, public sector, Ireland

\section{Introduction}

Managers in the public and state body sector increasingly work on processes of compliance, accountability, audit, assurance, risk and stakeholder consultation. These requirements have, to varying degrees, always been present, but in the past thirty years the processes have become more formal and explicit in the form of governance standards and codes of practice. 
In this paper, we will trace the development of formal requirements for governance in Ireland's public sector, comment on the requirements, assess aspects of implementation, and indicate some future directions and challenges.

In particular, we will focus on the area where very considerable development has occurred, the governance of state bodies.

\section{The meaning of governance}

Governance is an expansive term. As Pollitt \& Bouckaert (2011, p. 21) note, there are almost as many versions as there are authors who write about it. Hence, we have national, global, corporate, collaborative, regulatory, network and operational governance, to name just some. Rhodes (1996), in a relatively early paper, identified a number of uses of the term, including minimal state governance, new public management, self-organising networks and corporate governance. Subsequent authors such as Kjaer (2006) have added to discussion on the types and meanings of governance. We, in this paper, will focus on corporate governance and public sector governance.

Historically, the processes of governance in an institutional sense can be traced back to the formation of chartered companies as early as the sixteenth and seventeenth centuries (Cheffins, 2014). However, it is in the past half century and particularly since the 1990s that governance has developed both as a necessary component of professional practice and as a subject of academic interest.

The first code of governance practice emerged in the US in the 1970s, but it was the publication in the UK in 1992 of the Cadbury report (1992), and the first version of the UK Corporate Governance Code, which stimulated action in both private and, at a lag, public sectors around the world. Subsequently, the $\operatorname{OECD}(1999,2004,2015$; OECD/G20, 2015) published corporate governance principles, the World Bank (2000) published a corporate governance implementation framework, and the European Commission (2003) issued a plan for corporate governance.

Ireland, as we shall see, was an early adopter of corporate governance practices, not just in the private sector but also in the public sector where interest grew during the 1990s and into the following two decades. In the context of this volume we should note the early research contribution by Richard Boyle (1998) and by research colleagues at the Institute of Public Administration (IPA) (MacCarthaigh, 2007, 2009; McGauran et al., 2005). 
Returning to 1992, the genesis of the Cadbury report is instructive. It developed out of an initiative from the London Stock Exchange, the Bank of England, the UK Department of Trade and Industry, and the accounting profession. The associated code of practice became obligatory for listed companies on the London Stock Exchange. The code by extension applied to Irish companies listed on the London Stock Exchange, and in due course Irish companies listed on the Irish securities market came to comply with the updated UK Corporate Governance Code and the Irish Corporate Governance Annex.

Underlying the Cadbury report and associated code were the enduring principles of openness, integrity and accountability. These principles were particularly in focus in the period prior to Cadbury due to a number of high-profile corporate crises and failures involving poor oversight, bad management and fraud (Petrochilos, 2004). There was a confluence of other contributory factors which heightened interest, including concerns about the growth and spread of multinational corporations and the growing acceptance that a range of stakeholders have an interest in the operations of corporations. A long-standing concern surrounded the consequences of the growing separation of the owners of corporations from those, often differently motivated, managers who exercise day-to-day control.

Cadbury (1992) succinctly characterised corporate governance as 'the system by which companies are directed and controlled'. The OECD (1999) added that corporate governance specifies 'the distribution of rights and responsibilities among the different participants in the organization - such as the board, managers, shareholders, and other stakeholders - and lays down the rules and procedures for decision making'. Choosing from what Johnston (2015, p. 442) calls 'a cornucopia of definitions', we also note Tricker (2019, p. 4), who emphasises that corporate governance is about how power is exercised: 'it covers the activities of the board and its relationship with those managing the enterprise and with the shareholders or members, as well as the external auditors, regulators and other legitimate stakeholders'.

Tricker usefully distinguishes between management, which is responsible for running the enterprise, and governance, which ensures that it is running in the right direction and being run well. The Department of Finance (2019, p. 5) elaborates that 'good corporate governance provides clarity in relation to authority and responsibility, it supports effective decision making and it identifies the assurance and accountability arrangements that exist within any organisation'.

We will return to the matter of definitions later in the paper. 


\section{Transferring from private to public sector}

The transfer of norms and standards from private to public sector raises several issues. The key principles of openness, integrity and accountability are relevant to both sectors. Private sector business methods and innovations are, of course, instructive and useful. The 2001 Code of Practice for the Governance of State Bodies reflected this in its comment that the 'Corporate governance of state bodies should operate to the highest standards applicable in the business world generally' (Department of Finance, 2001, p. 1). This should not preclude a recognition of differences between both sectors that present particular challenges for corporate governance (Heald \& Steel, 2015; Hepworth, 1994; Percy, 1994).

The public sector operates under a range of political, social and economic objectives. These varying, and sometimes conflicting, objectives are not always capable of being operationally specified so as to measure outcomes. The absence of price signals in many areas of the public sector and the lack of a relatively clear analogue of, for example, private sector shareholder value make the measurement of performance particularly difficult.

The public sector operates under different statutory and ownership frameworks. Certainly, there are debates about the nature of private sector ownership, agency and trusteeship (Mayer, 2020). These issues are even more complex in the public sector. We can conceive of citizens as the ultimate owners of state assets, the Oireachtas as overseers and parliamentary scrutineers, the government as trustees and the public sector as managers. A chain of vertical accountability therefore runs from citizens to the Oireachtas, to government, to departments, to both local government and to agencies, and to public servants. Cross-hatching this vertical arrangement is a horizontal chain of accountability to public sector users who are citizen-owners with justifiably high expectations and who, in certain parts of the public sector, cannot opt out of the service. To flesh out the picture of public service accountability more fully, the conduct of public service business is audited by a statutory auditor mandated to report not just on financial statements, in line with accounting principles and standards, but also on the systems to ensure the public interest and value for money.

Acknowledging the foregoing, it seems clear that appropriate structures, guidelines, skills and competencies are required not just for the management of the public sector but for its corporate governance. 


\section{Theory and practice}

The formal study of corporate governance draws from several disciplines, including economics, finance, accounting, law, management and organisation behaviour.

\section{The agency problem}

An early and enduring focus of study has been the principal-agent problem arising out of the aforementioned separation of ownership from control. This issue did not suddenly spring up: as early as 1776 in the Wealth of Nations, Adam Smith pointed to the moral hazard associated with managing 'other people's money'. Berle \& Means (1932) provided a twentieth century seminal text for corporate governance by developing the argument that legal owners of a corporation are separated from day-to-day management. The dilemma is that owner-shareholders are effectively outsiders with less information at their disposal than self-interested insider managers, thereby leading to suboptimal performance. The challenge is how to get the agent with an information advantage and potentially selfish interests to act in the principal's best interests. The principal-agent perspective became, for a period, a dominant lens through which corporate governance was viewed, with major theoretical contributions from Jensen \& Meckling (1976) and Fama \& Jensen (1983), among many others, adding to an important stream of literature.

The principal-agent perspective raised issues of how to deal with the asymmetric information held by managers, and led to often misguided attempts to tackle goal conflict and to align shareholder and manager interests. One such approach was through carefully designed contracts for managers. Another was through the marketbased incentive of offering managers shares in the companies in which they worked. Indeed, taking a broader perspective, proponents of the market-based approach doubted the need for intervention through incentivising agent-managers, believing that underperforming companies would have to shed inefficient managers or risk being taken over.

From a public sector perspective the principal-agent debate raised important questions. For example, what issues arise from the exercise of managerial discretion in the public sector? According to Niskanen $(1968,1971)$, the asymmetrical information possessed by bureaucrats places them in a powerful position compared to politicians and allows them to pursue their self-interested objectives unless subjected to an 
active system of external control and accountability. These ideas were not uncontested. For example, Cromien (1986) provided such a challenge, particularly in the Irish context, and saw stronger grounds for trust between agents and principals in the public sector context than envisaged in some of the principal-agent literature. We will return to the issue of trust later in the paper.

A key question remains: Who are the principals in the public sector? The bilateral relationship implied by the principal-agent theory seems inadequate for a public sector context in which there are several principals. In the parliamentary governance chain referred to above, the citizens, and perhaps more particularly the electorate, select the parliament which in the Irish system appoints the executive which works with an impartial public service, recruited and promoted on basis of merit, who work with a range of state bodies and agencies. At this admittedly simplified level it is clear that the principal-agent debate, which has a central role in underpinning the development of corporate governance, is characterised and complicated by the breadth of its scope, the layers of its application and the status of its actors.

\section{Stakeholders}

Of course the principal-agent model is one of several theoretic approaches. From a public sector perspective, stakeholder theory has clear relevance. From this perspective, an organisation is not just responsible to its owners but also needs to take account of the interest of various stakeholders, including employees, customers and suppliers. Again in the public sector the position is somewhat more complex and stakeholders can extend to include citizens groups, user-committees, voluntary bodies and so forth. This range and plurality of stakeholders is a very recognisable feature of the public sector and state body landscape, and one which creates difficulties for steering, coordination and control, and indeed raises more general issues for governance such as corporate social responsibility and environmental stewardship. Stakeholders are brought together in public sector boards. Indeed, some of these stakeholders may exercise considerable influence at a higher level of policymaking. From the perspective of the boards of a state agency, the existence of multiple principals, different and potentially conflicting objectives, and varying and sometimes conflicting stakeholder interests presents difficult corporate governance challenges. 


\section{Public sector theories and reform: Context for corporate governance}

The trajectory of public sector reform has been outlined and assessed by MacCarthaigh (2017) and needs little further elaboration here. We will look at some of the themes underlying reform which help set the context for corporate governance in the public and state body sector.

Although they were not expressly linked, the development of public sector corporate governance in Ireland occurred alongside public sector liberalisation and reform. Both were influenced by developments in private sector management and governance.

Some forces which propelled interest in corporate governance - the separation of ownership and control, the recognition of a wider domain of stakeholders, the growth of supranational organisations bear some similarity to the forces driving liberalisation and reform. Other forces such as corporate failure are more the preserve of private sector corporate governance, though malpractice can occur in either sector.

For the purposes of this paper we briefly refer to two of the forces and research traditions associated with public sector reform, namely New Public Management (NPM) and Network Theory.

The adjective 'new' is somewhat misleading inasmuch as many of the underlying ideas predate the late 1980s, when NPM took shape. Indeed, NPM was declared dead as long ago as 2006 (Dunleavy et al., 2006). It is, however, instructive to examine some of the key ideas which indeed continue to have currency in public sector management.

Reforms flowing from NPM thinking include the transfer of what were regarded as private sector management methods to the public sector. These managerial approaches included the setting of clear expected standards, the measurement of performance, value for money, focus on the customer, the freedom to manage, accountability for outcomes and so forth.

The foregoing private sector managerial approach was complemented by a market-oriented economic approach. The latter advocated competition through contracting-out, consumer choice, incentive structures for managers and so forth.

The managerialism and marketisation associated with NPM which informed public sector reform abroad, particularly in the UK, Australia and New Zealand, challenged bureaucratic structures and behaviours and supported the creation, and some would say proliferation, of agencies and a fragmentation which resulted in a loss of vertical and horizontal coordination in public administration and governance (Laegreid \& Verhoest, 2010). The emphasis that NPM placed on 'steering', whether it be agencies or contracted-out services, 
created problems for governance not just in the elimination of certain elements of coordination but also in the increasing challenges to maintain and improve accountability and transparency. It is understandable that Ryan \& Ng (2000) argued that corporate governance frameworks afforded a measure of protection against some of the flexibility and risk-taking encouraged by NPM. This argument highlights the need for vigilance that corporate governance processes do not impair public sector innovation.

Efficiency was an important element in public sector reform in Ireland stretching back to the Strategic Management Initiative in 1992 but it is difficult to discern a continuing direct attributable influence of NPM thinking on public sector reform. Neither is it clearly present in thinking around public sector corporate governance in Ireland, which, in common with other countries, was driven by considerations of organisational fraud and failure, the need to provide reassurance to international inward investment and a specific concern for internal inefficiency, namely the separation of ownership from control.

Post-NPM thinking has moved beyond the relatively narrow focus on internal efficiency to look at the coalitions of stakeholders involved in modern public administration, public policymaking and public service delivery (Osborne, 2010). Public sector corporate governance is rightly concerned with coordinating the network of stakeholders involved in delivering complex integrated services. However, the plurality of stakeholders involved in these areas creates difficulties for public sector steering and coordination. Though we do not have space to deal with it here, there is a considerable literature dealing with what Borzel (1998, p. 253) calls the 'Babylonian variety' of network concepts and applications. The corporate governance literature, as we have seen, deals specifically with stakeholder theory. There is, however, much to be learned from the wider discourse on governance network theory.

\section{State bodies}

Corporate governance processes in the public sector in Ireland are most advanced in the case of state bodies.

The Register of Public Sector Bodies (Central Statistics Office, 2020) identifies 211 public sector bodies in the non-financial corporation sector and 39 in the financial corporation sector, along with 181 general government non-market agencies. The Code of Practice for the Governance of State Bodies refers to a broad state body categorisation: 
commercial, non-commercial and regulatory (Department of Public Expenditure and Reform, 2016, p. 11).

The Code of Practice for the Governance of State Bodies covers these diverse organisations, which vary not only in size but also in function, from caring and culture to water and hard infrastructure. Moreover, the state bodies and agencies were created and exist for varied and sometimes overlapping reasons. Some exist to provide merit goods such as education and healthcare, others exist to tackle negative externalities such as pollution, yet others have some of the qualities of natural monopolies and others again ensure security of supply. A common theme is that the market may not be able to supply the goods or services undertaken by the public sector at an affordable price, at least to some people.

In Ireland, since the 1990s, there has been a notable increase in the growth of state agencies. Agencification was driven to an extent by objectives of giving managers freedom to manage and of creating conditions for efficient operations, ideas that are consistent to some extent with NPM. However, agencies also allowed for separating policymaking from implementation, gaining access to external expertise, blurring the size of government, depoliticising certain decision-making and detaching service delivery from the political arena (Heald \& Steel, 2018; Hood, 1978; McGauran et al., 2005; OECD, 2008). The OECD (2008, p. 294) noted that developing new agencies was in line with developing new public sector capacity but that little thought was given to systematic oversight arrangements or governance in general.

\section{Codes of governance practice for state bodies}

We will specifically look at the codes of practice that have been developed for the governance of state bodies in Ireland within the wider context of public sector guidance, standards and frameworks.

\section{Evolution of guidance, codes and standards}

Ireland was an early adopter of codes of practice (Aguilera \& CuervoCazurra, 2009). The first manifestation of a code was in the form of the State Bodies Guidelines in 1992, prompted by concerns about aspects of the operations in certain state bodies. Among the other early adopters were Hong Kong, Canada and the UK. Actually, Ireland's State Body Guidelines slightly preceded the Cadbury report. The early adopters were common law countries with flexible legislative framework and reliance on previous judicial interpretations. By 
contrast, civil law countries, which are more subject to strictly interpreted legislation, were later adopters.

A sense of the evolution of public sector governance codes, guidelines and standards can be seen in Table 1 .

Table 1: Evolution of selected public sector governance reports, codes, guidelines and standards, 1992-2020

\begin{tabular}{|c|c|c|}
\hline$\overline{Y e a r}$ & Code/standard/guidance & Issued by \\
\hline 1992 & State Bodies Guidelines & Department of Finance \\
\hline$\overline{1995}$ & $\begin{array}{l}\text { Report of the Task Force to Review Controls } \\
\text { in Commercial State Companies Under the } \\
\text { Aegis of the Minister for Transport, } \\
\text { Energy and Communications }\end{array}$ & Government of Ireland \\
\hline$\overline{2001}$ & $\begin{array}{l}\text { Code of Practice for the Governance of } \\
\text { State Bodies }\end{array}$ & Department of Finance \\
\hline 2002 & $\begin{array}{l}\text { Report of the Working Group on the } \\
\text { Accountability of Secretaries General and } \\
\text { Accounting Officers (Mullarkey report) }\end{array}$ & Department of Finance \\
\hline 2009 & $\begin{array}{l}\text { Code of Practice for the Governance of State } \\
\text { Bodies; replaced } 2001 \text { code }\end{array}$ & Department of Finance \\
\hline 2010 & $\begin{array}{l}\text { Protocol for Civil Servants Nominated to the } \\
\text { Boards of Non Commercial State Bodies }\end{array}$ & Department of Finance \\
\hline 2012 & $\begin{array}{l}\text { Governance Code for Community, Voluntary } \\
\text { and Charitable Organisations (adopted by } \\
\text { Sports Ireland as Governance Code for Sport } \\
\text { in 2019) }\end{array}$ & $\begin{array}{l}\text { The Governance Code } \\
\text { Working Group }\end{array}$ \\
\hline 2012 & Governance of Irish Universities & $\begin{array}{l}\text { Higher Education } \\
\text { Authority; Irish University } \\
\text { Association }\end{array}$ \\
\hline 2014 & Guidelines on Appointments to State Boards & $\begin{array}{l}\text { Department of Public } \\
\text { Expenditure and Reform }\end{array}$ \\
\hline 2014 & The Civil Service Renewal Plan & $\begin{array}{l}\text { Department of Public } \\
\text { Expenditure and Reform }\end{array}$ \\
\hline 2014 & $\begin{array}{l}\text { Report of the Independent Panel on } \\
\text { Strengthening Accountability and } \\
\text { Performance in the Civil Service }\end{array}$ & $\begin{array}{l}\text { Department of Public } \\
\text { Expenditure and Reform }\end{array}$ \\
\hline 2015 & $\begin{array}{l}\text { Draft Corporate Governance Standard } \\
\text { for the Civil Service }\end{array}$ & $\begin{array}{l}\text { Department of Public } \\
\text { Expenditure and Reform }\end{array}$ \\
\hline 2015 & Health Service Executive Code of Governance & Health Service Executive \\
\hline 2015 & $\begin{array}{l}\text { Governance Principles and Governance } \\
\text { Framework for the Local Government Sector }\end{array}$ & $\begin{array}{l}\text { County and City } \\
\text { Management Association; } \\
\text { Association of Irish Local } \\
\text { Government; Institute of } \\
\text { Public Administration }\end{array}$ \\
\hline
\end{tabular}



Table 1: Evolution of selected public sector governance reports,
codes, guidelines and standards, 1992-2020 (Contd.)

\begin{tabular}{lll}
\hline Year & Code/standard/guidance & Issued by \\
\hline 2015 & Governance Framework Document: & Department of Justice and \\
& $\begin{array}{l}\text { The Department of Justice, Equality and } \\
\text { An Garda Síochána }\end{array}$ & Síochána An Garda \\
\hline 2016 & $\begin{array}{l}\text { Code of Practice for the Governance of } \\
\text { State Bodies; replaced 2009 code }\end{array}$ & $\begin{array}{l}\text { Department of Public } \\
\text { Expenditure and Reform }\end{array}$ \\
\hline 2017 & Code of Practice for the Governance of State & Department of Public \\
& Bodies: A guide to the implications for & Expenditure and Reform; \\
& Annual Financial Statements and the & Comptroller and Auditor \\
& Annual Report & General \\
\hline 2018 & THEA Code of Governance for Institutes & Technological Higher \\
& of Technology & Education Association \\
\hline 2018 & Charities Governance Code & Charities Regulator \\
\hline 2018 & Corporate Governance Standard for the & Department of Public \\
& Civil Service & Expenditure and Reform \\
\hline 2018 & Corporate Governance Framework of & Department of Public \\
& Department of Public Expenditure and & Expenditure and Reform \\
& Reform; updated 2019 & \\
\hline 2018 & Department of Finance Governance & Department of Finance \\
& Framework; updated 2019 & \\
\hline 2019 & Code of Practice for the Governance of & Education and Training \\
& Education and Training Boards & Board Finance and \\
& & Administrative Personnel \\
\hline 2019 & Code of Governance for Irish Universities; & Irish Universities \\
& replaced 2012 code & Association; Higher \\
& Education Authority \\
\hline & Code of Practice for the Governance of & Department of Public \\
& Diversity and Inclusion & \\
& Coditure and Reform \\
& on Non-Commercial State Bodies & Department of Public \\
Expenditure and Reform \\
\end{tabular}

The table attempts to capture a sense of the direction, sequencing and pace of public sector reports, codes and standards. The public sector landscape is actually even more crowded, with individual departments, bodies and agencies having their own governance arrangements. For example, in 2016, the Department of Justice and Equality published its own governance framework. It also has a range of oversight and 
corporate assurance agreements with bodies under its aegis such as An Garda Síochána, the Courts Service, the Criminal Assets Bureau and Forensic Science Ireland, among others. The table makes clear that corporate governance arrangements in the public sector are largely a phenomenon of the past twenty years and that the past decade has been particularly active.

Codes and standards lay down a set of norms and best-practice recommendations. They allow for the dissemination of best practice and, of course, are updated in line both with the evolution of practice and with lessons from both home and abroad. The codes exist within the structures of statutory and company law. Public sector bodies that are statutory corporations have their own enabling legislation, which may contain particular details about board structure and functioning or the role of the CEO. Other public sector bodies operate under the Companies Acts and are subject to the relevant statutory and fiduciary obligations.

We should therefore see codes of governance as a component in an overall corporate governance framework which also includes legislation, regulation, self-regulatory arrangements and organisational commitments (Department of Public Expenditure and Reform, 2016, p. 5).

In contrast to legislation, codes and standards are voluntary. Yoshikawa \& Rasheed (2009) argue that codes and standards confer a legitimacy on public sector bodies and that once adopted by some bodies, there is a normative pressure on others to follow. Hence, not only is better or best practice disseminated, in reality the codes become de facto obligations; a public sector body without a code or standard becomes not only an anomaly but also an object of concern.

Table 2 shows the evolution of the guidelines and codes for state bodies.

Table 2: Evolution of elements of the guidelines/codes of governance for state bodies, 1992-2016

\begin{tabular}{lcccc}
\hline Code content & $\begin{array}{c}1992 \\
\text { Guidelines }\end{array}$ & $\begin{array}{c}2001 \\
\text { Code }\end{array}$ & $\begin{array}{c}2009 \\
\text { Code }\end{array}$ & $\begin{array}{c}2016 \\
\text { Code }\end{array}$ \\
\hline Definition of corporate governance & - & Yes & Yes & Yes \\
\hline Objective/purpose of governance in state bodies & - & Yes & Yes & Yes \\
\hline Compliance with tax clearance procedures & - & Yes & Yes & Yes \\
\hline Processes for the disposal of assets & - & Yes & Yes & Yes \\
\hline $\begin{array}{l}\text { Guidance on principles of customer service } \\
\text { and customer charter }\end{array}$ & - & Yes & Yes & Yes \\
\hline
\end{tabular}




\section{Table 2: Evolution of elements of the guidelines/codes of governance for state bodies, 1992-2016 (Contd.)}

\begin{tabular}{|c|c|c|c|c|}
\hline Code content & $\begin{array}{c}1992 \\
\text { Guidelines }\end{array}$ & $\begin{array}{l}2001 \\
\text { Code }\end{array}$ & $\begin{array}{l}2009 \\
\text { Code }\end{array}$ & $\begin{array}{l}2016 \\
\text { Code }\end{array}$ \\
\hline $\begin{array}{l}\text { Need for statement of reserved functions } \\
\text { requiring board decisions }\end{array}$ & - & - & Yes & Yes \\
\hline $\begin{array}{l}\text { Clear operating procedures for the operation } \\
\text { of the board, including frequency of meetings, } \\
\text { training and briefing for new members }\end{array}$ & - & Yes & Yes & Yes \\
\hline Role of the chair, board and secretary & - & Yes & Yes & Yes \\
\hline Explicit guidance on role of chairperson & - & - & - & Yes \\
\hline Overlap with legislative provisions identified & Yes & Yes & Yes & Yes \\
\hline $\begin{array}{l}\text { Opportunity for elements to be waived with the } \\
\text { consent of the board (1992) or minister } \\
\text { ( } 2001 \text { onwards) }\end{array}$ & Yes & Yes & Yes & Yes \\
\hline
\end{tabular}

Code of conduct for employees and board members and ethics in public office

Requirement to have internal audit function and audit committee

\begin{tabular}{lllll}
\hline $\begin{array}{l}\text { Confirmation of procurement compliance } \\
\text { processes in place }\end{array}$ & Yes & Yes & Yes & Yes \\
\hline
\end{tabular}

\begin{tabular}{llccc}
\hline $\begin{array}{l}\text { Requirements of establishment of subsidiaries } \\
\text { and other decisions regarding diversification }\end{array}$ & Yes & Yes & Yes & Yes \\
\hline $\begin{array}{l}\text { Compliance with investment appraisal } \\
\text { requirements }\end{array}$ & Yes & Yes & Yes & Yes \\
\hline $\begin{array}{l}\text { Processes for sanction of remuneration of } \\
\text { directors and chairperson }\end{array}$ & Yes & Yes & Yes & Yes \\
$\begin{array}{l}\text { Reporting arrangements to the minister, } \\
\text { including annual reports }\end{array}$ & Yes & Yes & Yes & Yes \\
$\begin{array}{l}\text { Requirement to implement strategic and } \\
\text { corporate planning }\end{array}$ & Yes & Yes & Yes & Yes \\
$\begin{array}{l}\text { Board appointments, terms of appointments, } \\
\text { gender and diversity (also annex on gender } \\
\text { balance, diversity and inclusion 2020) }\end{array}$ & - & - & - & Yes \\
$\begin{array}{l}\text { Procedures to maintain appropriate } \\
\text { relationship with external auditor }\end{array}$ & & & & \\
$\begin{array}{l}\text { All committees should have written constitutions } \\
\text { and terms of reference }\end{array}$ & - & - & Yes & Yes \\
$\begin{array}{l}\text { Ensuring that confidential disclosure } \\
\text { processes are in place }\end{array}$ & - & - & Yes & Yes \\
\hline
\end{tabular}



Table 2: Evolution of elements of the guidelines/codes of governance
for state bodies, 1992-2016 (Contd.)

\begin{tabular}{|c|c|c|c|c|}
\hline Code content & $\begin{array}{c}1992 \\
\text { Guidelines }\end{array}$ & $\begin{array}{l}2001 \\
\text { Code }\end{array}$ & $\begin{array}{l}2009 \\
\text { Code }\end{array}$ & $\begin{array}{l}2016 \\
\text { Code }\end{array}$ \\
\hline $\begin{array}{l}\text { Processes to ensure that there is a separation } \\
\text { of roles at the top level }\end{array}$ & - & - & Yes & Yes \\
\hline $\begin{array}{l}\text { Emphasis on the importance of the role of } \\
\text { non-executive directors }\end{array}$ & - & - & Yes & Yes \\
\hline $\begin{array}{l}\text { Development of risk management, accountability } \\
\text { and internal control processes }\end{array}$ & - & - & Yes & Yes \\
\hline $\begin{array}{l}\text { Explicit statement of the comply or explain } \\
\text { principle }\end{array}$ & - & - & - & Yes \\
\hline $\begin{array}{l}\text { Presentation of the overall governance } \\
\text { framework for state/public bodies }\end{array}$ & - & - & - & Yes \\
\hline $\begin{array}{l}\text { Need to ensure effective internal control } \\
\text { structures and processes }\end{array}$ & - & - & - & Yes \\
\hline $\begin{array}{l}\text { Board effectiveness reviews through } \\
\text { self-evaluation structures }\end{array}$ & - & - & - & Yes \\
\hline $\begin{array}{l}\text { Extension of role of the audit committee to } \\
\text { audit \& risk committee }\end{array}$ & - & - & - & Yes \\
\hline $\begin{array}{l}\text { Clear mapping of relations with the Oireachtas, } \\
\text { minister and parent departments }\end{array}$ & - & - & - & Yes \\
\hline $\begin{array}{l}\text { Notification of legal disputes with other public } \\
\text { bodies }\end{array}$ & - & - & - & Yes \\
\hline
\end{tabular}

Source: Developed from Browne (2020).

\section{Reflections on guidance, codes and standards}

Table 2 shows the development of code content since the first guidelines in 1992. Since 1992, Ireland has developed and extended the scope and content of the codes, with major revisions in 2001, 2009 and 2016 and subsequent amendments and annexes. Measured crudely, by simple bulk alone, there has been significant development. The original nine-page guidelines of 1992 have expanded to a code which by 2020 numbered around 200 pages, when appendices and annexes and related guidance documents are added. Very cursory treatments in 1992 of reporting arrangements, remuneration, subsidiaries and acquisitions of state bodies, competitive tendering, disclosure of interests by board members, reports and accounts, investment appraisal and corporate planning have evolved by 2020 into detailed treatment of the roles of boards, board members and chairpersons; board effectiveness; ethics, disclosures and codes of 
conduct; business and financial reporting; risk management and audit arrangements; relations with the Oireachtas, ministers and parent departments; remuneration and superannuation; and quality customer service. To this, in 2020, was added an annex on gender balance, diversity and inclusion.

Clearly, the scope has broadened. Within this there has been a trajectory of additional reporting requirements which more recently opened out into values, principles and the importance of leadership and 'tone from the top'. A sense of how the codes and standards in Ireland's public sector may develop in the future can be gleaned from the UK Stewardship Code (Financial Reporting Council, 2020), which sets stewardship standards for asset owners and managers. This code espouses the principle that environmental and social issues be integrated along with governance into investments decisions. The growing acceptance of the importance of environmental, social and corporate governance issues seems likely to be embodied in the future development of the Irish codes.

While it is clear from the table that the scope of the codes has broadened, in some areas it has also intensified. One such area is the treatment of the role of the board. For example, the 2016 code introduced explicit treatment of the role of the chairperson and specified the chairperson's responsibilities for leadership, the demonstration of integrity and probity, the setting of expectations concerning culture, values and behaviours for the state body, and the setting of the tone of discussion at board level (Department of Public Expenditure and Reform, 2016, p. 18).

A common feature of Ireland's Code of Practice for the Governance of State Bodies, as it has evolved from 2001, is the 'comply or explain' approach which allows a degree of flexibility around certain provisions in the form of derogations, 'provided the objectives of those provisions can be achieved by other governance measures' (Department of Public Expenditure and Reform, 2016, p. 8).

The 'comply or explain' approach helps address the tension that arises between compliance-based codes and the need for managerial freedom, as, for example, prescribed in NPM thinking.

The aforementioned UK Stewardship Code is also interesting in this context inasmuch as it operates with an 'apply and explain' approach. This is clearly more restrictive and any move in this direction does not help resolve the management freedom dilemma. The need, for example, to meet certain financial performance targets might be weighed up differently in a 'comply or explain' context than in an 
'apply and explain' context. The stubborn fact, however, is that we have little systematic research evidence of how codes affect the behaviour of managers and boards, certainly in an Irish context.

Huse (2007, p. 32) viewed corporate governance in terms of 'the interactions of coalitions of actors inside and outside the firm and inside and outside the boardroom'. He drew attention to the different objectives and attributes of the actors and to their biased conceptions of corporate governance.

Authors such as Marnet (2008) have argued that codes of practice are necessary but also that issues concerning bias, the use of heuristics in decision-making, and the existence of conflict and of acquiescence are important in corporate governance settings. Perceptions are clearly also important. Adelberg \& Batson (1978), in an early research experiment on accountability, showed how the knowledge that a person's performance is to be evaluated can give rise to 'accountability apprehension' and lead to less effective but more defensible decisions. Research in this vein brings interesting insights which need greater coherence. Van Ees et al. (2009) have rightly promoted the case for a behavioural theory of boards and corporate governance.

The implementation and operation of codes of practice must also be seen in the context of research which has failed to demonstrate strong relationships between corporate performance and such board features as size, composition, independence, leadership structure and CEO pay (Dalton et al., 1998, 1999; Hermalin \& Weisbach, 2003; Tosi et al., 2000). This research goes beyond concerns of 'conformance versus performance' into fundamental issues in the understanding of the drivers of performance.

Looking in detail at the provisions of the 2016 code in Ireland it is clear that heavy demands are being made of board members and managers. We will use three examples - organisational culture, risk appetite and assurance processes - to help illustrate the challenges involved.

As we have seen, the chair of a state body is expected to set expectations regarding culture, values and behaviours, and the tone of discussion at board level. The Annex on Gender Balance, Diversity and Inclusion notes that effective culture builds on shared purpose and standards such as professionalism, honesty, integrity and accountability (Department of Public Expenditure and Reform, 2020, p. 5). It is indeed clear that an effective culture is a key component in ensuring that purpose and strategy are achieved.

In helping to address the challenging concept of culture, based as it is on underlying beliefs, values and behavioural norms, certain 
guidances and diagnostic tools are available to board members, chairpersons and senior managers. Initiatives such as internal and external focus groups; bilateral structured engagement with key stakeholders; employee engagement surveys; performance frameworks, including use of triple bottom line; reporting and disclosures; leadership, management and staff development programmes; critical consideration of purpose, mission and values, and how these are aligned with conduct and behaviours at all levels, are approaches that are used in seeking to assess the culture of an organisation. Against this background it is clear that the various actors in state body governance need time and competence-building in order to get to grips with and to meet their responsibilities.

A similar point can be made in other areas such as risk appetite. To pursue and deliver strategy outcomes requires both reasoned and responsible risk-taking. A risk appetite statement approved by a board specifies the risk level that can be pursued and tolerated in pursuit of an organisation's missions and priorities. Once again there are helpful tools and guidance to help assess the risk and one such, developed in the IPA from diverse examples, is illustrated in Table 3.

The approach illustrated in the table provides structured guidance on how to analyse risk appetite. The issue here is not the absence of analytical and guidance frameworks but the time and capacity-building required in constructing, validating, monitoring, reviewing and revalidating the framework statement across areas such as service and policy development, stakeholder engagement, new technology, cybersecurity, customer service, staff and talent management, reputation, financial performance and so forth. Making judgements in line with the template at a depth of engagement beyond ticking boxes is a major endeavour.

A third area which illustrates the demands on chairpersons, boards and managers concerns assurance arrangements. These require evidence, largely in the form of reports and reviews, both from inside and outside the organisation. Assurance arrangements are an important construct in building and maintaining the trust that underlies corporate governance relationships.

Professional practice is increasingly aware of the virtue of coordinating the assurance reports and reviews in a formalised structured framework which identifies and maps the main sources of assurance and enables their coordination. Such a framework includes the internal reports and reviews from board committees, senior management, internal audit, project teams and work groups. These 
Table 3: Illustration of a risk appetite template

\begin{tabular}{|c|c|c|c|c|c|c|c|c|c|c|}
\hline & \multicolumn{5}{|c|}{$\begin{array}{l}\text { Unacceptable } \\
\text { to take risk }\end{array}$} & \multicolumn{5}{|c|}{$\begin{array}{l}\text { Willing to pursue } \\
\text { opportunity }\end{array}$} \\
\hline Goal, activity or function & 1 & 2 & 3 & 4 & 5 & 6 & 7 & 8 & 9 & 10 \\
\hline 1 Service and product development & & & & & & & & & & \\
\hline $\begin{array}{l}2 \text { Policy development and } \\
\text { information sharing }\end{array}$ & & & & & & & & & & \\
\hline $\begin{array}{l}3 \text { Regulatory activity (profession, } \\
\text { sector, etc.) }\end{array}$ & & & & & & & & & & \\
\hline $\begin{array}{l}4 \text { Reform and change initiatives } \\
\text { focusing }\end{array}$ & & & & & & & & & & \\
\hline $\begin{array}{l}5 \text { Collaboration, joint ventures and } \\
\text { strategic alliances }\end{array}$ & & & & & & & & & & \\
\hline 6 Enforcement activity & & & & & & & & & & \\
\hline 7 Raising standards across the sector & & & & & & & & & & \\
\hline $\begin{array}{l}8 \text { Stakeholder engagement and } \\
\text { consultation }\end{array}$ & & & & & & & & & & \\
\hline $\begin{array}{l}9 \text { Compliance (legal, regulatory } \\
\text { and governance) }\end{array}$ & & & & & & & & & & \\
\hline 10 New technology/digital approaches & & & & & & & & & & \\
\hline 11 Cyber and information security & & & & & & & & & & \\
\hline 12 Staff/talent management & & & & & & & & & & \\
\hline $\begin{array}{l}13 \text { Financial (performance \& } \\
\text { stewardship) }\end{array}$ & & & & & & & & & & \\
\hline 14 Reputation and image & & & & & & & & & & \\
\hline 15 Customer service and experience & & & & & & & & & & \\
\hline
\end{tabular}

are complemented by external reports and reviews from regulatory bodies, external audit, and commissioned reports and reviews from third parties.

The outcome of these reports and reviews is a range of assurance on such things as internal risk management systems; compliance with laws, regulation and standards; corporate and financial performance; strategy implementation; and stakeholder engagement.

The benefits of such a formalised arrangement are quite clear. In acknowledging these benefits, we return, however, to the need for time and resources in order to properly implement such a framework.

In the context of a board which meets between ten and fifteen times per year, sometimes under time pressure and with limited resources, 
there are clear challenges. Implementation is time-consuming and capacity gaps must be addressed. In doing so it is sensible that public sector bodies should tailor obligations, to the degree possible within the code structure, to their size, objectives, and economic and social environment.

Ultimately, codes are positive if they are used as real instruments for good governance and to the extent that they are lived out in reality. The Charities Governance Code (Charities Regulator, 2018, p. 16) puts matters well in stating that it is when these values are lived out that they are at their most powerful'.

Finally, in relation to codes of practice for the governance of state bodies we return to the basic definition of governance. The 2001, 2009 and 2016 codes have roughly similar definitions. Most recently, the 2016 code states that 'Corporate governance compromises the systems and procedures by which organisations are directed, controlled and managed' (Department of Public Expenditure and Reform, 2016, p. 5).

In light of the discussion in this article we suggest that it is possible to develop this definition and propose the following: governance comprises the structures and arrangements put in place to ensure that the organisation fulfils its overall purpose and achieves the intended outcomes for its stakeholders. Governance is concerned with leadership and direction, roles and responsibilities, structures and processes for decision-making, accountability, risk management and internal controls, culture and related behaviours within the organisation, and the impact of the organisation on the environment and society.

Seeing governance in this way allows us to judge good governance in a wider perspective (Turnbull, 2012). It retains focus on important issues such as the need for clarity about roles, authority and responsibilities in public sector organisations and about assurance and accountability arrangements. It also incorporates the interests of stakeholders and society more generally.

\section{Conclusion}

Official guidance on public sector corporate governance in Ireland is nearly thirty years in existence. It has extended to all sectors of the public service and has evolved in both detail and scope through a series of reviews and updates. The future may bring additional requirements in social and environmental areas. 
Public sector corporate governance evolved from private sector initiatives, and the various guidance standards and codes in Ireland continue to bear the marks of this. The development of official guidance on public sector corporate governance in Ireland seems somewhat disconnected from the broadly contemporaneous process of public sector reform, though some common themes and concerns underlie both. Moreover, the literature on corporate governance in the public sector is somewhat underdeveloped compared to the literature on the private sector.

The spread across the public sector of corporate governance codes and standards, and the fact that they bear great similarities, indicates the dissemination of improved practice that has occurred but also the need for reviewing, tailoring and suitably adjusting to particular circumstances.

The codes and standards have increased the reporting requirements and the compliance workload on public sector boards and managers. Inevitably, therefore, the codes and standards require not just time and effort but also capacity-building.

As we near the thirtieth anniversary of the first official document, the State Bodies Guidelines, it seems appropriate to conduct meaningful structured research, review progress and address important questions. These questions include: Are we overloading the codes? What are the lessons from professional practice? What have been the consequences for performance? How has managerial freedom been affected? Are there impacts on the willingness to innovate? Is attention diverted from strategic decision-making into process management? How should we measure good governance? On the positive side we can ask, what are the success stories from which professional practice can learn? How can the different layers of the public sector best leverage the improved information flowing from corporate governance processes? From an overall perspective we might ask about the institutional evolution and direction of travel of corporate governance arrangements, the potential benefits that might ensue from integrating, or at least coordinating, the codes and standards across the public sector, and the appropriate custodianship arrangements for the codes.

The public sector, by its very nature, pursues economic and social objectives. In 2020 societies and economies have experienced economic and social shocks which will have important long-term consequences. 
At least for the short term under pandemic conditions and in the medium and longer terms as events unfold, public sector corporate governance needs to keep pace with the changing nature of labour force engagement, the changing demands on, and from, stakeholders, the challenges of remote leadership and governance, and the increasing scale and intensity of state activities.

\section{References}

Adelberg, S., \& Batson, D. C. (1978). Accountability and helping: When needs exceed resources. Journal of Personality and Social Psychology, 36 (2), $343-50$.

Aguilera, R. V., \& Ceuvo-Cazurra, A. (2009). Codes of good governance. Corporate Governance: An International Review, 17 (3), 376-87.

Berle, A., \& Means, G. (1932). The modern corporation and private property. New York: Macmillan.

Borzel, T. A. (1998). Organising Babylon - On the different conceptions of policy networks. Public Administration, 72 (2), 253-73.

Boyle, R. (1998). Governance and accountability in the Irish civil service [CPMR discussion paper 6]. Dublin: Institute of Public Administration.

Browne, J. (2020). The development of the code of governance in Irish state bodies: Mapping the evolution between 2001 and 2016. Doctorate in Governance paper, Institute of Public Administration, Dublin.

Cadbury, A. (1992). Report of the Committee on the Financial aspects of Corporate Governance [Cadbury report]. London: Gee Publishing.

Central Statistics Office. (2020). Register of public sector bodies: Ireland 2019. Cork: Central Statistics Office.

Charities Regulator. (2018). Charities governance code. Dublin: Charities Regulator.

Cheffins, B. R. (2014). The history of corporate governance. In M. Wright, D. Siegal, K. Keasey, \& I. Filatotchev (Eds), The Oxford handbook of corporate governance (pp. 46-64). Oxford: Oxford University Press.

Cromien, S. (1986). Public expenditure and the bureaucracy: Comment. In J. Bristow \& D. McDonagh (Eds), Public expenditure: The key issues (pp. 121-6). Dublin: Institute of Public Administration.

Dalton, D. R., Daily, C. M., Ellstrand, A. E., \& Johnson J. L. (1998). Metaanalytic reviews of board composition, leadership structure, and financial performance. Strategic Management Journal, 19, 269-90.

Dalton, D. R., Daily, C. M., Johnson, J. L., \& Ellstrand, A. E. (1999). Number of directors and financial performance: A meta-analysis. Academy of Management Journal, 42, 674-86.

Department of Finance. (2001). Code of practice for the governance of state bodies. Dublin: Department of Finance. 
Department of Finance. (2009). Code of practice for the governance of state bodies. Dublin: Department of Finance.

Department of Finance. (2019). Governance framework. Dublin: Department of Finance.

Department of Justice and Equality. (2016). Governance framework for the Department of Justice and Equality. Dublin: Department of Justice and Equality.

Department of Public Expenditure and Reform. (2014a). Guidelines on appointments to state boards. Dublin: Department of Public Expenditure and Reform.

Department of Public Expenditure and Reform. (2014b) Report of the Independent Panel on Strengthening Accountability and Performance in the Irish Civil Service. Dublin: Government Reform Unit, Department of Public Expenditure and Reform.

Department of Public Expenditure and Reform. (2016). Code of practice for the governance of state bodies. Dublin: Department of Public Expenditure and Reform.

Department of Public Expenditure and Reform. (2018). Corporate governance standard for the civil service. Dublin: Department of Public Expenditure and Reform.

Department of Public Expenditure and Reform. (2019). Corporate governance framework. Dublin: Department of Public Expenditure and Reform.

Department of Public Expenditure and Reform. (2020). Code of practice for the governance of state bodies: Annex on gender balance, diversity and inclusion. Dublin: Department of Public Expenditure and Reform.

Dunleavy, P., Margetts, H., Bastow, S., \& Tinkler, J. (2006). New Public Management is dead - Long live digital-era governance. Journal of Public Administration Research and Theory, 16 (3), 467-94.

European Commission. (2003). Communication from the Commission to the Council and the European Parliament: Modernising company law and enhancing corporate governance in the European Union - A plan to move forward. Brussels: European Commission.

Fama, E. F., \& Jensen, M. (1983). Separation of ownership and control. Journal of Law and Economics, 26, 301-25.

Financial Reporting Council. (2020). The UK stewardship code 2020. London: Financial Reporting Council.

Government of Ireland. (1995). Report of the task force to review controls in commercial state companies under the aegis of the Minister for Transport, Energy and Communications. Dublin: The Stationery Office.

Heald, D., \& Steel, D. (2015). Making the governance of public bodies work: Chair-chief executive relationships in practice. Public Money and Management, 35 (4), 257-64.

Heald, D., \& Steel, D. (2018). The governance of public bodies in terms of austerity. The British Accounting Review, 50, 149-60. 
Hepworth, N. (1994). Principles of corporate governance and the public services. In Public Finance Foundation (Ed.), Corporate governance in the public sector (pp. 9-16). London: CIPFA.

Hermalin, B. E., \& Weisbach, M. S. (2003). Boards of directors as an endogenously determined institution: A survey of the economic literature. Economic Policy Review, 9 (1), 7-26.

Hood, C. (1978). Keeping the centre small: Explanations of agency type. Political Studies, 26 (1), 30-46.

Huse, M. (2007). Boards, governance and value creation: The human side of corporate governance. Cambridge: Cambridge University Press.

Jensen, M. C., \& Meckling, W. H. (1976). Theory of the firm: Managerial behavior, agency costs, and capital structure. Journal of Financial Economics, 3, 305-60.

Johnston, K. (2015). Conclusion. In A. Massey \& K. Johnston (Eds), The International handbook of public administration and governance (pp. 242-61). Cheltenham: Edward Elgar.

Kjaer, A. M. (2006). Governance. Malden: Polity Press.

Laegreid, P., \&Verhoest, K. (2010). Governance of public sector organisations: Proliferation, autonomy and performance. Basingstoke: Palgrave Macmillan.

MacCarthaigh, M. (2007). The corporate governance of regional and local public service bodies in Ireland [CPMR research report 8]. Dublin: Institute of Public Administration.

MacCarthaigh, M. (2009). The corporate governance of commercial state-owned enterprises in Ireland [CPMR research report 9]. Dublin: Institute of Public Administration.

MacCarthaigh, M. (2017). Public sector reforms in Ireland: Countering crisis. Basingstoke: Palgrave.

Marnet, O. (2008). Behaviour and rationality in corporate governance. Abington: Routledge.

Mayer, C. (2020). Ownership, agency and trusteeship: An assessment. Oxford Review of Economic Policy, 36 (2), 223-40.

McGauran, A., Verhoest, K., \& Humphreys, P. C. (2005). The corporate governance of agencies in Ireland: Non commercial national agencies [CPMR research report 6]. Dublin: Institute of Public Administration.

Niskanen W. A. (1968). The peculiar economics of bureaucracy. American Economic Review, 58 (2), 293-305.

Niskanen W. A. (1971). Bureaucracy and representative government. Chicago: Aldine.

OECD. (1999). Principles of corporate governance. Paris: OECD.

OECD. (2004). Principles of corporate governance. Paris: OECD.

OECD. (2008). Ireland: Towards an integrated public service. Paris: OECD.

OECD. (2015). Guidelines on corporate governance of state-owned enterprises. Paris: OECD.

OECD/G20. (2015). Principles of corporate governance. Paris: OECD. 
Osborne, S. P. (2010). The new public governance: Emerging perspectives on the theory and practice of public governance. London: Routledge.

Percy, I. (1994). Corporate governance in the public sector. In Public Finance Foundation (Ed.), Corporate governance in the public sector (pp. 1-8). London: CIPFA.

Petrochilos, G. A. (2004). Managerial economics: A European text. Basingstoke: Palgrave.

Pollitt, C., \& Bouckaert, G. (2011). Public management reform: A comparative analysis - New Public Management, governance and the neo-Weberian state. Oxford: Oxford University Press.

Rhodes, R. A. (1996). The new governance: Governing without government. Political Studies, 44, 652-67.

Ryan, C., \& Ng, C. (2000). Public sector corporate governance disclosures: An examination of annual reporting practices in Queensland. Australian Journal of Public Administration, 59 (2), 11-23.

Tosi, H. L., Werner, S., Katz, J. P., \& Gomez-Mejia, L. R. (2000). How much does performance matter? A meta-analysis of CEO pay studies. Journal of Management, 26 (2), 301-39.

Tricker, B. (2019). Corporate governance: Principles, policies and practices. Oxford: Oxford University Press.

Turnbull, S. (2012). The limitations of corporate governance best practice. In T. Clarke \& D. Branson (Eds), Handbook of corporate governance (pp. 428-49). London: Sage.

Van Ees, H., Gabrielsson, J., \& Huse, M. (2009). Towards a behavioral theory of boards and corporate governance. Corporate governance: An international review, 17 (3), 307-19.

World Bank. (2000). Corporate governance: A framework for implementation. Washington: The World Bank Group.

Yoshikawa, T., \& Rasheed, A. A. (2009). Convergence and corporate governance: Critical review and future directions. Corporate Governance: An International Review, 17 (3), 388-404. 